Research Paper

\title{
INVESTIGATION OF ORGANOCHLORINE PESTICIDES IN SEDI- MENT IN CAU HAI LAGOON, CENTRAL VIETNAM
}

\section{Doan Thi Quynh Tram ${ }^{1}$, Tran Chau Phong Nha ${ }^{2}$, Hua Thi Thuy Linh ${ }^{1}$, Bach Quang Dung Pham Thi Le Thuy', Nguyen Minh Ky,"*}

\section{ARTICLE HISTORY}

Received: February 08, 2020 Accepted: April 14, 2020

Publish on: April 25, 2020

\section{ABSTRACT}

Cau Hai lagoon, located to the south of Phu Loc District, Thua Thien Hue province and the part of the Tam Giang - Cau Hai lagoon system is one of the largest lagoon systems in Southeast Asia. Cau Hai lagoon is a waterbody receiving overflowing water from the inland rivers and streams, so it is possible to accumulate organochlorine pesticides (chlorinated organic groups) in sediments. This study used Gas Chromatography-Mass Spectrometry (GC/MS) method to investigate the content of some organochlorine pesticides in sediment samples. In general, the results showed the presence of some organochlorine pesticides in the sample such as $\alpha-H C H, \beta-H C H, \delta-H C H$, Heptachlor, Aldrin, Heptachlor epoxide and Endosulfan. Some toxic chemicals had concentration less than the limit of detection of the analytical method. The results of this research showed the scientific and practical significance, which is an important database for concentration of organochlorine pesticides in sediment of Cau Hai lagoon, Thua Thien Hue province, Central Vietnam.

\section{$\triangle$ NGUYEN MINH KY}

Corresponding author:nmky@hcmuaf.edu.vn ${ }^{1}$ Nong Lam University of Ho Chi Minh City, Vietnam

${ }^{2}$ College of Sciences, Hue University, Vietnam

${ }^{3}$ Viet Nam Meteorological and Hydrometeorological Administration, Ha Noi, Vietnam
Keywords: Sediments, organochlorine pesticides, Central Vietnam, Cai Hai, lagoon.

\section{Introduction}

Crop protection chemicals penetrate into the water body from various sources such as wastewater, dry condensation, rainwater, runoff, erosion, etc These chemicals are sparingly soluble in water and capaple of accumulating in animal organisims' fat tissue or being adsorbed by suspended solid particles. After settling on the bottom, they will accumulate in the bottom layer organisms and enter the food chain, eventually entering the human body (Connell, 1994). Sediment pollution has adverse impacts on ecosystems and poses potential risks to benthos (Nhan et al., 2001). Estuarine sediments are frequently polluted with hydrocarbons (e.g. polycyclic aromatic hydrocarbons) from some reasons such as fuel spills and industrial wastes (Bach et al., 2005). Due to persistent characteristics in the environment and toxicity risks, the compounds of organicchlorine pesticides (OCPs) in sediments have been extensively researched (Xue et al., 2006; Wang et al., 2007; Darko et al., 2008; 
Farshid, 2015; Wang et al., 2016; Kampire and Rubidge, 2017). In Vietnam, there are also many works interested in plant protection chemicals in water, sediments or aquatic species (Toan, 2015; Doan et al., 2018; Trinh et al., 2019). Pesticide contamination considered shows impacts on organisms, ecosystems and the environment (Jinglan et al., 2011; Cheng et al., 2013; Jayaraj et al., 2016). In nature, the rotation cycle of pesticides is very complicated and has long-lasting characteristics. In addition to the role of human impacts, pesticides enter the environment due to the impact of many factors such as physics, chemistry, geography, climate, hydrology, migration and even biological characteristic of plants and animals (Nguyen, 2005). In particular, after settling to the bottom in the form of sediments, they will accumulate in the bottom layer organisms and enter the food chain, eventually entering the human body (Nhan et al., 2001). The distribution and residual of chemical pesticides in water or sediment cause problems for health as well as ecological environment (Wang et al., 2016; Unyimadu et al., 2019).

Meanwhile, Cau Hai is one of the lagoon belonging to Tam Giang - Cau Hai lagoon system. Tam Giang - Cau Hai system is the largest lagoon in Southeast Asia, located about $7 \mathrm{~km}$ northeast of Hue city, at geographical coordinates of $16^{\circ} 14^{\prime}$ to $16^{\circ} 42^{\prime}$ North latitude and from $107^{\circ} 22^{\prime}$ to $107^{\circ} 57^{\prime}$, East longitude (IMOLA, 2010). The total length of $68 \mathrm{~km}$, Tam Giang-Cau Hai lagoon has an area of nearly $22,000 \mathrm{ha}$, is located on the territory of $33 \mathrm{com}$ munes of Phong Dien, Quang Dien, Phu Vang, Phu Loc and Huong Thuy towns (Thua Thien Hue Provincial People's Committee, 2008; Nguyen and Nguyen, 2014). Cau Hai lagoon has a basin shape, the average depth of the lagoon is $1.4 \mathrm{~m}$. The surface of the water is about $104 \mathrm{~km} 2$ and it connects to the East Sea through Tu Hien estuary (IMOLA, 2010). The hydrological conditions of Cau Hai lagoon are influenced by hydrological factors of rivers and the sea. Cau Hai lagoon is facing many critical issues such as oil pollution, eutrophication, coliform contamination and anthropogenic chemicals (Frignani et al., 2004). Zoning of water quality in Cau Hai lagoon showed phosphate, ammonia contents were not suitable for aquaculture and total coliform were higher than the standard (Truong et al., 2018). The study of pesticide residues accumulated in sediment samples in Cau Hai lagoon is very necessary. Previously, a number of studies identified OCPs in the Tam Giang-Cau Hai lagoon system but there has not been any study to assess the cumulative levels in sediment samples of Cau Hai lagoon (Doan et al., 2018). Therefore, we conducted the study "Investigation of organochlorine pesticides in sediment in Cau Hai lagoon, Central Vietnam" with the aim of providing basic information about the concentration of pesticides in sediment in the Cau Hai lagoon, Thua Thien Hue province. The study focused on the survey of 10 types of pesticides in sediments including $\alpha-\mathrm{HCH}, \beta-\mathrm{HCH}, \delta-\mathrm{HCH}, \gamma-$ $\mathrm{HCH}$, Heptachlor, Aldrin, Heptachlor epoxide, Endosulfan, p,p'-DDE, m,p'-DDD. These are active ingredients with common characteristics such as environmental sustainability, good solubility in fatty acids, adipose tissue, low solubility in water and high toxicity. At the same time, they have the ability to accumulate permanently, especially it causes acute and chronic toxicity to animals and humans through the food chain.

\section{Methods}

\subsection{Research subjects}

Subjects of the study: OCPs in sediments include $\alpha-\mathrm{HCH}, \beta-\mathrm{HCH}, \delta-\mathrm{HCH}, \gamma-\mathrm{HCH}$, Heptachlor, Aldrin, Heptachlor epoxide, Endosulfan, p,p'-DDE, m,p'-DDD in Cau Hai lagoon, Thua Thien Hue Province, Central Vietnam.

Sampling location: Samples were collected at 07 locations (S1 to S7) as shown in Fig. 1 and Table 1. 


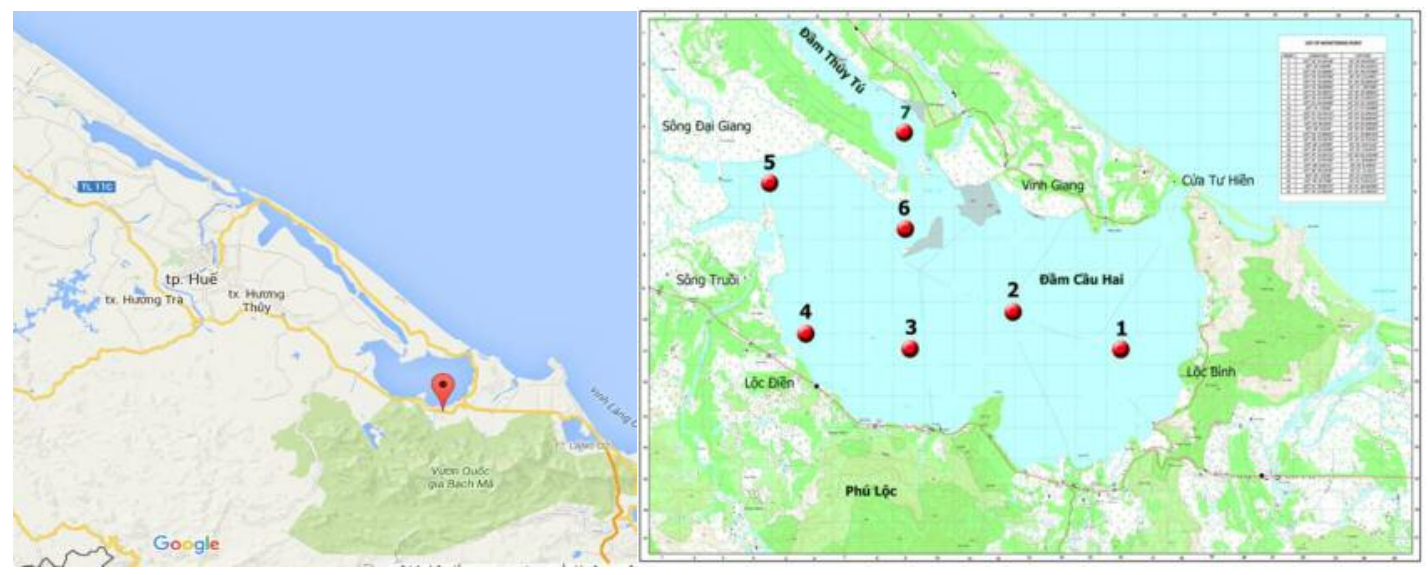

Fig. 1. Cau Hai lagoon system and sampling area

Table 1. Location of the sampling sites

\begin{tabular}{|c|c|c|c|c|c|}
\hline \multirow{2}{*}{ Symbol } & \multirow{2}{*}{$\begin{array}{l}\text { Number of } \\
\text { samples (n) }\end{array}$} & \multicolumn{2}{|c|}{ Coordinate } & \multirow{2}{*}{$\begin{array}{c}\text { Sampling } \\
\text { period }\end{array}$} & \multirow{2}{*}{ Weather } \\
\hline & & Latitude & Longitude & & \\
\hline S1 & 3 & $107^{0} 53^{\prime} 30.469^{\prime \prime}$ & $16^{0} 18^{\prime} 30.00953^{\prime \prime}$ & n & \multirow{7}{*}{$\begin{array}{l}\text { Sunny } \\
\text { Cloudless sky } \\
\text { Light winds } \\
\mathrm{T}=27.5-30.5^{\circ} \mathrm{C}\end{array}$} \\
\hline $\mathrm{S} 2$ & 3 & $107^{0} 51 ' 32.352^{\prime \prime}$ & $16^{0} 19^{\prime} 11.24612 "$ & 후 & \\
\hline S3 & 3 & $107^{0} 49^{\prime} 33.618^{\prime \prime}$ & $16^{0} 18^{\prime} 55.76839 ”$ & $\overline{\bar{\Delta}}$ & \\
\hline S4 & 3 & $107^{\circ} 48^{\prime} 02.870^{\prime \prime}$ & $16^{0} 19^{\prime} 10.57116^{\prime \prime}$ & है & \\
\hline S5 & 3 & $107^{0} 47^{\prime} 33.976 "$ & $16^{0} 21^{\prime} 38.64816^{\prime \prime}$ & $\frac{0}{0}$ & \\
\hline S6 & 3 & $107^{0} 50^{\prime} 01.034^{\prime \prime}$ & $16^{0} 21^{\prime} 06.24157^{\prime \prime}$ & 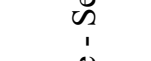 & \\
\hline S7 & 3 & $107^{0} 49^{\prime 2} 29.758^{\prime \prime}$ & $16^{0} 22^{\prime} 53.61114^{\prime \prime}$ & $\Xi$ & \\
\hline
\end{tabular}

\subsection{Methods}

\subsubsection{Sampling method}

In this study, the sampling procedure was carried out using the standard method of TCVN 6663-15:2004 (ISO 5667-15:1999). The sediment samples were taken using a special sampling drill at a depth of $0-10 \mathrm{~cm}$. The collected sample is wrapped in aluminum foil and transferred to the laboratory, allowed to dry naturally at room temperature. The sample after natural drying, rough grinding and sieving through a 2 $\mathrm{mm}$ diameter was sieved to remove stones, grit, roots, etc. Then, the sample is continuously finely ground, and sifted with a pore size $<0.1$ $\mathrm{mm}$, stored in aluminum foil and kept in a clean, dry plastic bag at $-20^{\circ} \mathrm{C}$.

Samples after pretreatment were extracted by Soxhlet extraction method. Soxhlet extraction method for 10 hours and 3-4 cycles/hour, extraction solvent is a mixture of $300 \mathrm{~mL} \mathrm{n}$ hexane: acetone with a volume ratio of $1: 1$
(Nhan et al., 1999; ATSDR, 2007; Pham et al., 2011). The extract sample is concentrated to $2-5$ $\mathrm{mL}$ on a rotary evaporator. Concentrated extracts are treated with concentrated $\mathrm{H} 2 \mathrm{SO} 4$ and continue to be washed with water until no more acid is present. Next, shake with the activated copper chip to remove the sulfide compounds. The extract after removal of the sulfide compounds is transferred to a florisil column for cleaning. Elute the florisil column with $50 \mathrm{~mL}$ of $\mathrm{n}$ hexane: acetone mixture with a corresponding volume ratio of $9: 1$, elution rate of 4-5 $\mathrm{mL} / \mathrm{minute}$. The eluate is vacuum-rotated at $40-$ $50^{\circ} \mathrm{C}$ to a volume of $2-5 \mathrm{~mL}$ and transferred to a $15 \mathrm{~mL}$ glass tube with a small amount of nhexane. The solution is further evaporated by solvent flow of nitrogen to a volume of less than $1 \mathrm{~mL}$, adding internal standard phenanthrenen$\mathrm{d} 10$ and making up to volume of $1 \mathrm{~mL}$ for analysis by the chromatographic system GC - MS. 


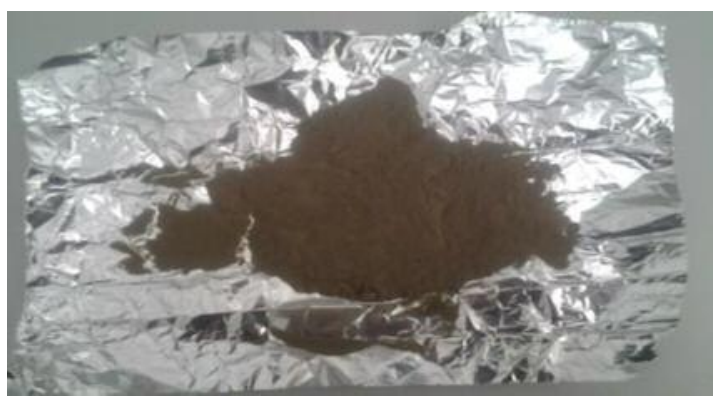

Fig. 2. Pre-treated sediment sample

\subsubsection{Analytical method}

The qualitative and quantitative analysis of pesticides was conducted on gas Chromatography - Mass spectrometry GC - MS (Agilent Technologies 7890A System). Based on the study Pham et al. (2010) the working conditions and temperature program of GC-MS device are established. In particular, Separation column: capillary column Rtx ${ }^{\circledR}$-CLPesticides (column length $30 \mathrm{~m}$, internal diameter $0.25 \mathrm{~mm}$, thickness of the static phase layer of $0.25 \mu \mathrm{m}$ ); Gas bearing He (purity $99.9995 \%$ ); Sample pump room temperature: $250 \mathrm{oC}$; Column oven temperature: $85 \mathrm{oC}$; Model of pump: splitless, the sample is automatically pumped with a volume of $3 \mathrm{~mL}$; Flow rate: $1 \mathrm{~mL} /$ minute. The working conditions of the mass spectrometer are as follows: Ionizing source: EI $70 \mathrm{EV}$ source; Ionizing source temperature: $230 \mathrm{oC}$; Detector voltage: $1447 \mathrm{~V}$; Interface temperature: $250 \mathrm{oC}$; Cutting solvent time: 9 minutes; Scan mode (SCAN) and fragment selection analysis mode (SIM); Post run temperature: $285 \mathrm{oC}$.

\subsubsection{Assessing reliability}

Proceed to extract OCPs in a sediment sample several times with a mixture of n-hexane: acetone solvent with a volume ratio of $1: 1$. By the time the extract was no longer detectable OCPs when analyzed on the GC - MS. This pattern is called the background pattern. Add $10 \mu \mathrm{L}$ of the OCPs standard solution with a concentration of each substance of $40 \mathrm{ng} / \mathrm{g}$ to the background sample. Conduct a recovery survey of the analytes of interest on the matrix to assess the reliability of the analytical procedure. The recovery
(Rev) is calculated by the formula (1):

$$
\operatorname{Rev}(\%)=\frac{\left(\mathrm{C}_{\mathrm{m}+\mathrm{c}}-\mathrm{C}_{\mathrm{m}}\right)}{\mathrm{C}_{\mathrm{c}}} .100
$$

where $\mathrm{C}_{\mathrm{m}+\mathrm{c}}$ is the concentration of organochlorine pesticides in the standardized sample $(\mathrm{ng} / \mathrm{g}) ; \mathrm{C}_{\mathrm{m}}$ is the concentration of organochlorine pesticides in the background sample $(\mathrm{ng} / \mathrm{g}) ; \mathrm{C}_{\mathrm{c}}$ is the concentration of organochlorine pesticides in the standard sample (ng/g). In addition, the repeatability of the method is assessed through relative standard deviations (RSD) by comparing the calculated RSD to the value $\mathrm{RSD}_{\text {Horwitz: }}$

$$
\mathrm{RSD}_{\text {Horwitz }}=2^{(1-0,5 \mathrm{lgC})}
$$

If $\mathrm{RSD} \leq \frac{1}{2} \mathrm{RSD}_{\text {Horwitz }}$ is accepted (Miller and Miller, 1988; Pham, 2006).

\subsubsection{Statistical methods}

The results are processed by software Aligent G1701EA (GC/MSD ChemStation). Experimental results are processed by statistical methods and using software Excel 2013 and SPSS 13.0 with significance level of 5\%. ANOVA (analysis of variance) test was employed to exam the difference of pesticides levels in different categories of sampling sites. The Pearson correlation coefficient is used to evaluate the relationship between pesticides levels.

\section{Results and discussion}

\subsection{The reliability of the analytical methods}

Assessing the reliability of the analytical procedure, the process of surveying the recovery of analyte substances on the base sample is shown in Table 2.

The average recovery efficiency of 10 pesticides needed to be analyzed is relatively high, reaching values ranging from 74 to $104 \%$. In particular, the recovery efficiency of analytes such as $\beta-\mathrm{HCH}$, Heptachlor, m, p'-DDD with high results respectively 101, 104 and $103 \%$. At the same time, the RSD ensures a good repeata- 
bility, with a small range of 1.0 to $9.7 \%$ (RSD $<13 \%$ ). Thus, this procedure is suitable for analyzing the concentrations of pesticides in the experimental sample which is sediment - a sample with a sulfide content and the sample background contains many complex components.

Table 2. Recovery of pesticides in the spiked background sample $40 \mathrm{ng} / \mathrm{g}$

\begin{tabular}{|c|c|c|c|c|c|c|}
\hline No. & Chemistry & $\operatorname{Rev}_{1}(\%)$ & $\operatorname{Rev}_{2}(\%)$ & $\operatorname{Rev}_{3}(\%)$ & $\operatorname{Rev}_{\mathrm{tb}}(\%)$ & RSD (\%) \\
\hline 1 & $\alpha-\mathrm{HCH}$ & 79 & 83 & 76 & 79 & 4.4 \\
\hline 2 & $\beta-\mathrm{HCH}$ & 99 & 101 & 102 & 101 & 1.5 \\
\hline 3 & $\delta-\mathrm{HCH}$ & 98 & 100 & 96 & 98 & 2.0 \\
\hline 4 & $\gamma-\mathrm{HCH}$ & 89 & 90 & 97 & 92 & 4.7 \\
\hline 5 & Heptachlor & 103 & 105 & 104 & 104 & 1.0 \\
\hline 6 & Aldrin & 80 & 79 & 91 & 83 & 8.0 \\
\hline 7 & $\begin{array}{l}\text { Heptachlor } \\
\text { epoxide }\end{array}$ & 87 & 97 & 80 & 88 & 9.7 \\
\hline 8 & Endosulfan & 99 & 103 & 94 & 99 & 4.6 \\
\hline 9 & p,p'-DDE & 71 & 76 & 74 & 74 & 3.4 \\
\hline 10 & m,p'-DDD & 104 & 101 & 103 & 103 & 1.5 \\
\hline
\end{tabular}

The average recovery efficiency of 10 pesticides needed to be analyzed is relatively high, reaching values ranging from 74 to $104 \%$. In particular, the recovery efficiency of analytes such as $\beta-\mathrm{HCH}$, Heptachlor, m, p'-DDD with high results respectively 101, 104 and $103 \%$. At the same time, the RSD ensures a good repeatability, with a small range of 1.0 to $9.7 \%$ (RSD $<13 \%$ ). Thus, this procedure is suitable for analyzing the concentrations of pesticides in the experimental sample which is sediment - a sample with a sulfide content and the sample background contains many complex components.

3.2. Investigation of fluctuations of pesticides concentration in Cau Hai lagoon sediments

In general, the former study showed that indicating potential health risks for fish consumers related to the trace elements in Cau Hai lagoon (Tran et al., 2018). They are mainly associated with lithogenic matter and also is most likely the result of erosion process in the lagoon. The trends of lagoon contamination (e.g. sediment samples) indicated that Cau Hai lagoon is still slightly increasing (Frignani et al., 2007). The study of Duong et al. (2018) determined three toxic elements $(\mathrm{Pb}, \mathrm{As}, \mathrm{Hg})$ in the surface sediment and to assess the ecological risk in this area. With the selected analytical process, the study analyzes the pesticides in sediment samples of Cau Hai lagoon in Thua Thien Hue province, Central Vietnam. The results of analyzing residues of pesticides in the samples are shown in Table 3. Active ingredients $\alpha-\mathrm{HCH}$ were found at the monitoring locations $\mathrm{S} 2, \mathrm{~S} 3$, S5 and S6. The ANOVA analysis presented the statistically significant differences among $\alpha$ $\mathrm{HCH}$ levels in the monitoring sites $(\mathrm{F}=21.090$, $\mathrm{p}=0.001)$. The distribution of HCHs in developing countries may explain the use of pesticides in agriculture in the past (Li et al., 2012). The content of $\delta-\mathrm{HCH}$, Heptachlor and Endosulfan was detected at all sampling points in sediments in Cau Hai lagoon. Results of the ANOVA test showed the statistically significant differences of $\beta-\mathrm{HCH}(\mathrm{F}=47.985, \mathrm{p}=0.001)$ and $\delta-\mathrm{HCH}(\mathrm{F}=$ $17.805, \mathrm{p}=0.001)$. Particularly, the content of $\gamma$-HCH, p,p'-DDE and m,p'-DDD showed no findings in the analytical samples. Comparing results of research on dioxins content in sediments in Iran shows that the content is equivalent to $8.66 \mathrm{ng} / \mathrm{g}$ (Farshid, 2015). Similarly, the content of dioxins analyzed for surface sediments of Lake Honghu (China) is valued at $9.19 \mathrm{ng} / \mathrm{g}$ and has an ecological risk (Yun et al., 2014). 
Table 3. Concentration of organochlorine pesticides in the sediment in Cau Hai lagoon (ng/g)

\begin{tabular}{rlccccccc}
\hline No. & Chemistry & $\mathrm{S} 1$ & $\mathrm{~S} 2$ & $\mathrm{~S} 3$ & $\mathrm{~S} 4$ & $\mathrm{~S} 5$ & $\mathrm{~S} 6$ & $\mathrm{~S} 7$ \\
\hline 1 & $\alpha-\mathrm{HCH}$ & - & $0.23 \pm 0.12$ & $0.02 \pm 0.01$ & - & $1.12 \pm 1.02$ & $0.17 \pm 0.03$ & - \\
2 & $\beta-\mathrm{HCH}$ & - & $0.24 \pm 0.32$ & $1.80 \pm 0.22$ & $0.02 \pm 0.02$ & $1.03 \pm 1.06$ & $0.17 \pm 0.02$ & - \\
3 & $\delta$-HCH & $1.06 \pm 0.21$ & $1.24 \pm 0.76$ & $0.67 \pm 0.23$ & $0.50 \pm 0.27$ & $1.23 \pm 0.74$ & $1.97 \pm 0.25$ & $1.76 \pm 0.34$ \\
4 & $\gamma-\mathrm{HCH}$ & - & - & - & - & - & - & - \\
& $\sum \mathrm{HCH}$ & $1.06 \pm 0.62$ & $1.71 \pm 0.45$ & $2.49 \pm 1.21$ & $0.52 \pm 0.22$ & $3.38 \pm 2.10$ & $2.31 \pm 1.03$ & $1.76 \pm 0.23$ \\
5 & Heptachlor & $13.50 \pm 2.34$ & $2.98 \pm 0.23$ & $9.98 \pm 3.43$ & $8.74 \pm 2.37$ & $5.93 \pm 1.29$ & $27.56 \pm 4.56$ & $14.87 \pm 3.71$ \\
6 & Aldrin & $2.00 \pm 1.02$ & - & $0.16 \pm 3.45$ & - & - & $0.11 \pm 0.03$ & - \\
7 & $\begin{array}{l}\text { Heptachlor } \\
\text { epoxide }\end{array}$ & - & - & $0.02 \pm 0.01$ & - & - & $0.04 \pm 0.02$ & - \\
8 & Endosulfan & $15.15 \pm 3.42$ & $15.30 \pm 5.67$ & $17.22 \pm 2.43$ & $15.74 \pm 4.53$ & $14.16 \pm 2.32$ & $21.12 \pm 3.49$ & $21.30 \pm 2.39$ \\
9 & p,p'-DDE & - & - & - & - & - & - & - \\
10 & m,p'-DDD & - & - & - & - & - & - & - \\
\hline
\end{tabular}

Note: Mean $\pm S D, n=3$; “-”:Not detected.

The area around the Cau Hai lagoon is at risk due to flooding, water pollution and over-exploitation (IMOLA, 2010). Regarding to the water quality, in the study of Dang et al. (2019) indicated that the nutrient availability and abundance of the phytoplankton community in lagoon. Besides, in the sediment samples taken from Cau Hai lagoon showed that is only slightly contaminated by trace elements (heavy metals) and these distributions were mainly influenced by river inputs (Giuliani et al., 2011). In this study, the results of analyzing pesticides in the sediment of Cau Hai lagoon show $\sum \mathrm{HCH}$ oscillate $0.52 \pm 0.22$ to $3.38 \pm 2.10 \mathrm{ng} / \mathrm{g}$. $\sum \mathrm{HCH}$ content in sediment at all points exceeded the impact threshold value TELs. There are 6 points that exceed the PELs impact value level according to Canadian environmental quality guidelines (Canadian Council of Ministers of the Environment, 2002) and no $\gamma$-HCH was detected in all sediment samples. This is explained by the nature of the $\mathrm{HCH}$ isomers in descending order: $\beta$ $\mathrm{HCH}>\delta-\mathrm{HCH}, \alpha-\mathrm{HCH}>\gamma-\mathrm{HCH}$. Therefore, it is possible that the $\gamma-\mathrm{HCH}$ active substance in the sediment has decomposed (Connell, 1994).

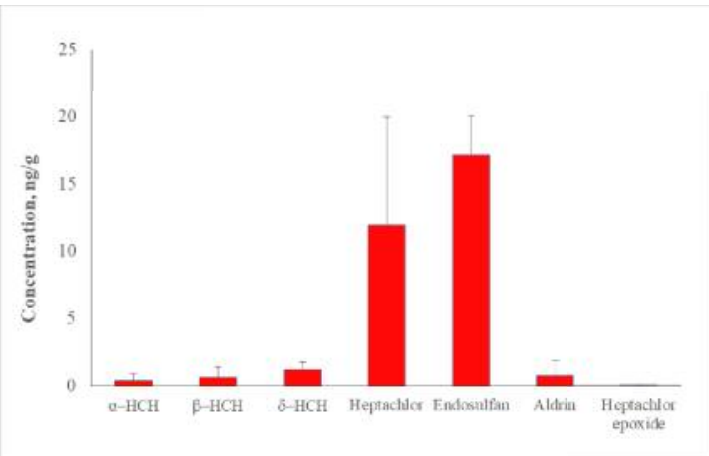

Fig. 3. Concentration of pesticides in sediment Through the ANOVA test, there were statistically significant differences between the Heptachlor levels $(\mathrm{F}=209.529, \mathrm{p}=0.001)$ as well as the Endosulfan levels $(\mathrm{F}=14.812, \mathrm{p}=0.001)$ of monitoring sites. The combined concentration of organchlorine pesticides in sediments in Cau Hai lagoon is shown in Fig. 3. Comparison of results with studies in China showed high levels of $\mathrm{HCH}$ sesidues with levels $1.02 \mathrm{ng} / \mathrm{g}$ (Hongxuan and Weiguo, 2016). Meanwhile, the concentration of pesticides in the sediment at the study sites is shown through the relatively high levels for Heptachlor and Endosulfan. This can be explained by the use of pesticides in agricultural production and through the erosion process, with 
the contribution of rain as one of the causes of pesticides accumulation in sediments (Bian et al., 2010). Due to the development of agricultural and aquacultural activities is increasing the pressure on the environment by transfer fertilizers and pesticides into the lagoon system (Nguyen and de Vries, 2009). The economic activities is an important reason impact on sediment and water quality of the lagoon. In addition, active ingredients such as Endosulfan are derived from their use in rat-killing activities during animal husbandry or agricultural production (Carriger et al., 2011; De Roma et al., 2017).
In the Cau Hai lagoon, fresh water is coming into the lagoon via the rivers. The rivers flow through urban areas and carry a lot of sediment to the lagoon which may be contained the compounds of OCPs. The sediment transported into the lagoon happens mostly in the flooding. The total sediment transport from the rivers through the Thuan An inlet is $1.43 \mathrm{~mm}^{3} /$ year during the flood season (Nghiem et al., 2008). Moreover, to evaluate the relationship between the parameters of pesticides in sediments in Cau Hai lagoon, correlation analysis results are shown in Table 4.

Table 4. Analysis of correlation among parameters of pesticides in sediment

\begin{tabular}{llllll}
\hline & $\alpha-\mathrm{HCH}$ & $\beta$-HCH & $\delta$-HCH & Heptachlor & Endosulfan \\
\hline$\alpha$-HCH & 1.000 & & & & \\
$\beta$-HCH & $0.253^{*}$ & 1.000 & & & \\
$\delta$-HCH & $0.515^{*}$ & $-0.312^{*}$ & 1.000 & & \\
Heptachlor & -0.345 & -0.219 & 0.633 & 1.000 & \\
Endosulfan & $-0.612^{*}$ & -0.161 & $0.690^{*}$ & $0.782^{*}$ & 1.000 \\
\hline
\end{tabular}

*Correlation is significant at the 0.05 level (2-tailed); $n=21$.

Correlation analysis of parameters of pesticides parameters in sediments was conducted in previous studies to find a link between them (Sun et al., 2008; Dirbaba et al., 2018). In this study, the results of correlation analysis showed the relationship among $\alpha-\mathrm{HCH}$ and, $\beta-\mathrm{HCH}, \delta$ $\mathrm{HCH}$ and Endosulfan $(\mathrm{p}<0.05)$. In particular, the correlation between $\alpha-\mathrm{HCH}<>\beta-\mathrm{HCH}, \alpha-\mathrm{HCH}$ $<>\delta-\mathrm{HCH}$ and $\alpha-\mathrm{HCH}<>$ Endosulfan were $0.253,0.515$ and -0.612 , respectively. The content of $\beta-\mathrm{HCH}$ in sediments and $\delta-\mathrm{HCH}$ shows a negative correlation with the corresponding coefficient of $-0.312(p<0.05)$. As for the Endosulfan parameter, there is also a good relationship with $\delta-\mathrm{HCH}$ and Heptachlor and Pearson correlation is quite high, respectively $0.690,0.782(\mathrm{p}<0.05)$. Comparison with another study showed a positive correlation between the content of $\sum \mathrm{HCHs}<>$ Heptachlor $(\mathrm{r}=$ $0.560, \mathrm{p}=0.01)$, Heptachlor $<>$ Heptachlor epoxide $(\mathrm{r}=0.536, \mathrm{p}=0.01)$ and that indicates the distribution of pesticides related to potential sources of pollution (Dirbaba et al., 2018).

\subsection{Risk assessment of pesticides in sedi- ments}

OCPs is known as an ecological toxin, persistent and highly bioaccumulating (Bai et al., 2015; Ahmed et al., 2015). Exposure to active ingredients such as HCHs and DDTs can cause serious health effects such as endocrine disorders, cancer and neurological and immune problems (Ize-Iyamu et al., 2007). To assess risks, the study uses Canadian sediment quality guidelines to consider the ecological risks of Cau Hai lagoon (Canadian Council of Ministers of the Environment, 2002). Accordingly, the threshold value of TELs impact of DDD, DDE and DDT respectively $1.22,2.07,1.19 \mathrm{ng} / \mathrm{g}$, while the results of sediment analysis in Cau Hai are below the detection threshold. The results showed that the content of some pesticides in the sediment was very low and ecologically safe. However, the analysis results showed the presence of other active substances such as HCHs, Heptachlor, Aldrin, Endosulfan. In recent priods the water dynamics is decreasing again and the sediments 
is recorded as an increase of porosity and a decrease of the content of sand (Frignani et al., 2007). Therefore, they can be stored and bioaccumulated through food chains, affecting human health as well as affecting ecosystems. The interventions to reduce the erosion are needed to protect the lagoon and the people living in $\mathrm{Cau}$ Hai lagoon (Eriksson and Persson, 2014). The erosion might cause great problems for local public around the lagoon and lead to the risk, changed sediment transport and water quality.

Table 5. Acceptable limits of pesticides in sediments

\begin{tabular}{cccc}
\hline \multirow{2}{*}{ No. } & Parameter & \multicolumn{2}{c}{ Canadian regulations on sediment quality (ng/g) } \\
\cline { 3 - 4 } & Aldrin and Dieldrin & $\begin{array}{c}\text { Temporary impact threshold } \\
(\text { ISQG/TELs) }\end{array}$ & Affect level (PELs) \\
\hline 1 & Dieldrin & 0.71 & 4.3 \\
2 & Endrin & 2.67 & 62.4 \\
3 & DDD & 1.22 & 7.81 \\
4 & DDE & 2.07 & 374 \\
6 & DDT & 1.19 & 4.77 \\
7 & DDT, DDD and DDE & & 2.74 \\
8 & Heptachlor & 0.6 & \\
9 & Heptachlor and Heptachlor & & 0.99 \\
\hline
\end{tabular}

Note: <TELs: Rarely harmful; PELs $\leq$ and $\geq$ TELs: Some cases may be harmful; > PELs: Constantly harmful.

In general, sediments in ponds and lakes are considered as places for sustainable storage of organic matter such as pesticides and will affect human health through bioaccumulation (Farshid, 2015; Unyimadu et al., 2018). Because of the rapid industrial development, the risks of pollution levels need to alarm for local community around lagoon areas (Thanh et al., 2004). The results show that the concentration of Heptachlor ranges from $2.98 \pm 0.23$ to $27.56 \pm 4.56 \mathrm{ng} / \mathrm{g}$. Heptachlor content in sediment at all monitoring points S1-7 exceeded the PELs influence level $(>2.74 \mathrm{ng} / \mathrm{g})$ according to Canadian environmental quality guidelines. In particular, the positions S1, S6, S7 with Heptachlor amount exceeds the value of PELs many times. The remaining content values such as Aldrin fluctuated from $0.11 \pm 0.03$ to $2.00 \pm 1.02 \mathrm{ng} / \mathrm{g}$; Heptachlor epoxide approx. $0.02 \pm 0.01$ to $0.04 \pm 0.02 \mathrm{ng} / \mathrm{g}$; and Endosulfan reach the threshold of $14.16 \pm$ 2.32 to $21.30 \pm 2.39 \mathrm{ng} / \mathrm{g}$. In addition, $\mathrm{p}, \mathrm{p}$-DDE, $\mathrm{m}, \mathrm{p}$ '-DDD values were not detected within the method limit of analysis.

\section{Conclusion}

Investigation of fluctuations of pesticides concentration by the analyzing process in $\mathrm{Cau}$ Hai lagoon area has good recovery and repeatability. The analytical results show that in Cau Hai sediment contains a concentration of some pesticides with high concentrations such as $\alpha$ $\mathrm{HCH}, \beta-\mathrm{HCH}, \delta-\mathrm{HCH}$, Heptachlor, Aldrin. The correlation analysis process showed the relationship of some pesticides, such as $\alpha-\mathrm{HCH}, \beta$ $\mathrm{HCH}, \delta-\mathrm{HCH}$ and Endosulfan $(\mathrm{p}<0.05)$. The results have shown some risks of pesticide contamination in sediments affecting bottom organisms of lagoon ecosystems as well as public health issues. Thus, the research is a premise and basis for providing useful scientific information to local communities in the consumption of some benthic species in Cau Hai lagoon, Central Vietnam. In the future, research should be conducted 
with a comprehensive assessment of the accumulation mechanism of these chemicals in relation to sediment samples and benthic organisms in the lagoon ecosystem.

\section{References}

1. Agency for Toxic Substances and Disease Registry (ATSDR), 2007. Toxicological profile for heptachlor and heptachlor epoxide. Atlanta, Georgia: U.S. Department of health and human services, Public Health Service.

2. Ahmed, G., Anawar, H.M., Takuwa, D.T., Chibua, I.T., Singh, G.S., Sichilongo, K., 2015. Environmental assessment of fate, transport and persistent behavior of dichlorodiphenyltrichloroethanes and hexachlorocyclohexanes in land and water ecosystems. International Journal of Environmental Science and Technology, 12: 2741-2756.

3. Bach, Q.D., Kim, S.J., Choi, S.C., Oh, Y.S., 2005. Enhancing the intrinsic bioremediation of PAH-contaminated anoxic estuarine sediments with biostimulating agents. Journal of Microbiology, 43 (4): 319-324.

4. Bai, J., Lu, Q., Zhao, Q., Wang, J., Gao, Z., Zhang, G., 2015. Organochlorine pesticides $(O C P s)$ in wetland soils under different land uses along a 100-year chronosequence of reclamation in a Chinese estuary. Scientific Reports, 5: 17624.

5. Bian, C., Jiang, W., Song, D., 2010. Terrigenous transportation to the Okinawa Trough and the influence of typhoons on suspended sediment concentration. Continental Shelf Research, 30: 1189-1199.

6. Canadian Council of Ministers of the Environment, 2002. Canadian Sediment Quality Guidelines for the Protection of Aquatic life. Winnipeg: Canadian Council of Ministers of the Environment.

7. Carriger, J.F., Hoang, T.C.., Rand, G.M., Gardinali, P.R., Castro, J., 2011. Acute Toxicity and Effects Analysis of Endosulfan Sulfate to Freshwater Fish Species. Archives of Environ- mental Contamination and Toxicology, 60: 281289.

8. Cheng, W.W., Anping, Z., Weiping, L., 2013. Risks from sediments contaminated with organochlorine pesticides in Hangzhou, China. Chemosphere, 90 (9): 2341-2346.

9. Connell, D.W., 1994. The octanol-water partition coefficient. In: Handbook of Ecotoxicology, Oxford: Blackwell Scientific Publications, 2: 311-320.

10. Dang, T.N.Y., Nguyen, T.H., Pham, K.L., Harada, H., Brion, N., Duong, V.H., Nguyen, V.H., Venterink, H.O., 2019. Effects of nutrient supply and nutrient ratio on diversity-productivity relationships of phytoplankton in the Cau Hai lagoon, Vietnam. Ecology and Evolution, 9 (10): 5950-5962.

11. Darko, G., Akoto, O., Oppong, C., 2008. Persistent organochlorine pesticide residues in fish, sediment organochlorine pesticide residues in fish, sediment and water from Lake Bosomtwi, Ghana. Chemosohere, 72 (1): 21-24.

12. De Roma, A., Rossini, C., Riverso, C., Galiero, G., Esposito M., 2017. Endosulfan poisoning in canids and felids in the Calabria region of southern Italy. Journal of Veterinary Diagnostic Investigation, 29 (1): 122-125.

13. Dirbaba, N.B., Li, S., Wu, H., Yan, X., Wang, J., 2018. Organochlorine pesticides, polybrominated diphenyl ethers and polychlorinated biphenyls in surficial sediments of the Awash River Basin. Ethiopia. PLoS ONE, 13 (10): e0205026.

14. Doan, T.Q.T., Hoang, T.L., Nguyen, M.K., Tran, T.A.M., 2018. Assessment of organochlorine pesticides in some fish species in Cau Hai lagoon, Thua Thien Hue province. Joural of Science Technology and Food, 17 (1): 90-99.

15. Duong, V.H., Tran, T.D., Tran, N.T., Duong, T.C., 2018. Investigation and ecological risk assessment of $\mathrm{Pb}, \mathrm{As}$ and $\mathrm{Hg}$ in sediment of Tam Giang-Cau Hai lagoon, Thua Thien Hue province. Vietnam Journal of Science and Technology, 56 (2C): 72-79. 
16. Eriksson, E.L., Persson, M.H., 2014. Sediment tranSport and coaStal evolution at Thuan An inlet, Vietnam. Journal of Water Management and Research, 70: 169-179.

17. Farshid, K., 2015. Assessment of Organochlorine Pesticide Residues in Water, Sediments and Fish from Lake Tashk, Iran. Achievements in the Life Sciences, 9 (2): 107111.

18. Frignani, M., Bellucci, L.G., Albertazzi, S., Piazza, R., Moret I., Nguyen H.C., Zangrando R., 2004. Polychlorinated biphenyls in sediments of the Tam Giang-Cau Hai Lagoon (Central Vietnam) - First results. Proceedings of international symposium on halogenated environmental organic pollutants and POPs, Germany, 66: 3608-3614.

19. Frignani, M., Piazza, R., Bellucci, L.G., Nguyen, H.C., Zangrando, R., Albertazzi, S., Moret, I., Romano, S., Gambaro, A., 2007. Polychlorinated biphenyls in sediments of the Tam Giang-CauHai Lagoon, Central Vietnam. Chemosphere, 67: 1786-1793.

20. Giuliani, S., Romano, S.,, Turetta, C., Nguyen, H.C., Bellucci, L.G., Capodaglio, G., Mugnai, C., Dang, H.N., Frignani, M., 2011. Soils and sediments of the Thua Thien-Hue Province (central Vietnam): recognizing trace element sources and the likely influence of natural events. Journal of Environmental Monitoring, 13: 1383-1392.

21. IMOLA, 2010. Project report of Integrated management of lagoon activities. Hue: IMOLA.

22. Ize-Iyamu, O.K., Asia, I.O., Egwakhide, P.A., 2007. Concentrations of residues from organochlorine pesticide in water and fish from some rivers in Edo State Nigeria. International Journal of Physical Sciences, 2: 237-241.

23. Jayaraj, R., Megha, P., Sreedev, P., 2016. Organochlorine pesticides, their toxic effects on living organisms and their fate in the environment. Interdisciplinary toxicology, 9 (3-4): 90100.

24. Jinglan, F., Mengxiao, Z., Qun, L., Jian- hui, S., Jiajia, G., 2011. Residues of organochlorine pesticides (OCPS) in upper reach of the Huaihe River, East China. Ecotoxicology and Environmental Safety, 74 (8): 2252-2259.

25. Hongxuan, L., Weiguo, L., 2016. Distribution characteristics of organochlorine pesticides in soil, water, and sediment from the Bahe River, China. Environmental Forensics, 17 (1): 80-86.

26. Kampire, E., Rubidge, G., 2017. Characterization of polychlorinated biphenyls in surface sediments of the North End Lake, Port Elizabeth, South Africa. Water, 43: 646-654.

27. Li, W., Yang, H., Gao, Q., Pan, H., Yang, H., 2012. Residues of organochlorine pesticides in water and suspended particulate matter from Xiangshan Bay, East China Sea. Bulletin of Environmental Contamination and Toxicology, 89: 811-815.

28. Miller, J.C., Miller, J.N., 1988. Statistics for Analytical Chemistry, Ellis Horwood Limited.

29. Nghiem, T.L, Stive, M.J.F., Wang, Z.B., Verhagen, H.J., Vu, T.T.T., 2008. Hydrodynamics and morphodynamics of a seasonally forced tidal inlet system. Journal of Water Resources and Environmental Engineering, Thuy loi University, 23: 114-124.

30. Nguyen, H.L., Nguyen, M.K., 2012. Climate change awareness and practice of fishing communities in Tam Giang-Cau Hai lagoon in Thua Thien Hue province. Journal of Science and Technology, University of Danang, 53 (4): 33- 40.

31. Nguyen, N.T.T., de Vries, M.B., 2009. Predicting trends in water quality in the coastal zone of TT-Hue, Vietnam - An assessment of impacts of rice culture and aquaculture. Asian and Pacific Coasts, 2: 148-154.

32. Nguyen, X.K., 2005. Assess the residues of chlorine mechanical pesticides in some biological objects and environment in Thua Thien Hue lagoon. Hanoi: PhD thesis in Chemistry, Vietnam National University.

33. Nhan, D.D., Am, N.M., Carvalho, F.P., 
Villeneuve, J.-P., Cattini, C., 1999. Organochlorine pesticides and $P C B$ s along the coast of North Vietnam. Science of the Total Environment, 238: 363-371.

34. Nhan, D.D., Carvalho, F.P., Am, N.M., Tuan, Q.T., Yen, N.T.H., Villeneuve, J.P., Cattini, C., 2001. Chlorinated pesticides and PCBs in sediments and mollusks from fresh-water canals in the Hanoi region. Environmetal Pollution, 112: 311-320.

35. Pham, L., 2006. Atomic spectrum analysis method. Hanoi: National University Press.

36. Pham, M.H., Pham, H.V., Nguyen, D.G.C, 2010. Simultaneous analysis of residues of organochlorine pesticides and Polychlorinated Biphenyls in leaf squid (Sepioteuthis lessoniana) at some locations in North and Central. Journal of Science and Technology, 48 (2A): 4652.

37. Pham, M.H., Zita, S., Tu, B.M., Pham, H.V., Fabrice, G.R., 2011. Pesticide pollution in agricultural areas of North Viet Nam: Case study in Hoang Liet and Minh Dai communes. Environmental Polluttion, 159: 3344-3350.

38. Sun, J.H., Wang, G.L., Zhang, G., Li, J., Chai, Y., 2008. Correlation analysis and risk assessment of organochlorine pesticides in surface sediments from the Yellow River. Acta Sci. Circumst., 28 (2): 342-348.

39. Thanh, T.D., Saito, Y., Huy, V.D., Nguyen, V.L., Ta, T.K.O., Tateishi, M., 2004. Regimes of human and climate changes in Vietnam. Regional Environmental Change, 4: 49-62.

40. Thua Thien Hue Provincial People's Committee, 2008. Thua Thien Hue Province Tourism and Lagoon Development Program till 2012. Thua Thien Hue.

41. Toan, V.D., 2015. Residue of select organochlorine pesticides (OCPs) in sediment from Vietnam's CauBay river and their impact on agricultural soil and human health. Polish Journal of Environmental Studies, 24: 301-306.

42. Tran, T.A.M., Leermakers, M., Hoang, T.L., Nguyen, V.H., 2018. Metals and arsenic in sediment and fish from Cau Hai lagoon inViet- nam: Ecological and human health risks. Chemosphere, 210: 175-182.

43. Trinh, T.T., Hoang, Q.A., Le, T.T., Vi, M.L., Nghiem, X.T., Nguyen, T.H.Y., Nguyen, L.A., Tran, M.T., Tu, B.M., 2019. Distributions and seasonal variations of organochlorine pesticides, polychlorinated biphenyls, and polybrominated diphenyl ethers in surface sediment from coastal areas of central Vietnam Marine Pollution Bulletin, 44: 28-35.

44. Truong, V.D., Vu, N.U., Nguyen, T.L., Mac, N.B., 2018. Zoning aquaculture water quality in Cau Hai lagoon, Thua Thien - Hue province. Journal of Science- Can Tho Univeristy, 54 (6B): 120-128.

45. Unyimadu, J.P., Osibanjo, O., Babayemi, J.O., 2018. Polychlorinated biphenyls (PCBs) in River Niger, Nigeria: Occurrence, distribution and composition profiles. Toxicology and Industrial Health, 34 (1): 54-67.

46. Unyimadu, J.P., Osibanjo, O., Babayemi, J.O., 2019. Concentration and Distribution of Organochlorine Pesticides in Sediments of the Niger River, Nigeria. Journal of Health and Pollution, 9 (22): 190606.

47. Wang, H., He, M., Lin, C., Quan, X., Guo, W., Yang, Z., 2007. Monitoring and assessment of persistent organochlorine residues in sediments from Daliaohe River watershed, northeast of China. Environmental Monitoring and Assessment, 133 (1-3): 231-242

48. Wang, D., Yang, S., Wang, G., Gao, L., Wang, Y., Jiang, Q., Chen, Y., 2016. Residues and Distributions of Organochlorine Pesticides in China's Weihe River. Polish Journal of Environmental Studies, 25: 1285-1292.

49. Xue, N., Zhang, D., Xu, X., 2006. Organochlorinated pesticide multiresidues in surface sediments from Beijing Guanting reservoir. Water Research, 40 (2): 183-94.

50. Yun, X., Yang, Y., Liu, M., Wang, J., 2014. Distribution and ecological risk assessment of organochlorine pesticides in surface sediments from the East Lake, China. Environmental Science and Pollution Research, 21: 10368-10376. 